\title{
WHAT'S A CONSTITUTION AMONG FRIENDS?- UNBALANCING ARTICLE III
}

\author{
Craig A. STERN ${ }^{\dagger}$
}

The judicial Power of the United States, shall be vested in one supreme Court, and in such inferior Courts as the Congress may from time to time ordain and establish. The Judges, both of the supreme and inferior Courts, shall hold their Offices during good Behavior, and shall, at stated Times, receive for their Services, a Compensation, which shall not be diminished during their Continuance in Office.

-The Constitution of the United States, Article III, Section 1

\section{INTRODUCTION}

Nine out of ten experts agree that a straightforward reading of the first section of the third article of the United States Constitution does not work. ${ }^{1}$ Such a reading, it is said, would doom the District of

† Associate Professor, Regent University Law School; B.A. 1975, Yale University; J.D. 1978, University of Virginia. The author thanks Mary Bunch, Ric Giuliano, Scott Golden, Chris Kachouroff, Mike Schutt, John Tuskey, Eric Welsh, the American Center for Law and Justice, and Regent University for their assistance and support.

1 See, e.g., Thomas v. Union Carbide Agric. Prods. Co., 473 U.S. 568, 582-83 (1985) (observing that "[a]n absolute construction of Article III is not possible" in reviewing congressional arbitration requirements unaccompanied by substantial review by an Article III judge); Northern Pipeline Constr. Co. v. Marathon Pipe Line Co., 458 U.S. 50, 93-94 (1982) (White, J., dissenting) (stating that questions regarding Article III limits "on Congress' [s] ability to create adjudicative institutions ... can no longer be answered by looking only to the constitutional text"); ERWIN CHEMERINSKY, FEDERAL JURISDICIION $\$ 4.1$, at 209-10 (2d ed. 1994) (arguing that it would be unrealistic, despite the text of Article III, to declare every legislative court unconstitutional); George D. Brown, Article III as a Fundamental Value-The Demise of Northern Pipeline and Its Implications for Congressional Power, 49 OHIO ST. L.J. 55, 56 (1988) (analyzing the Supreme Court's retreat from a strict construction of Article III as possibly indicating a lowered estimation "of the importance of [A]rticle III tribunals"); Richard H. Fallon, Jr., Of Legislative Conerts, Administrative Agencies, and Article III, 101 HARV. L. REV. 915, 916-17 (1988) (calling a "return to '[A]rticle III literalism' virtually unthinkable"); Judith Resnik, The Mythic Meaning of Article III Courts, 56 U. CoLO. L. REV. 581, 586 (1985) (noting that a literal reading of Article III is "defeated by an ultimately insurmountable response-reality"); Richard B. Saphire \& Michael E. Solimine, Shoring up Article III: Legislative Court Doctrine in the Post CFTC v. Schor Era, 68 B.U. L. REV. 85, 126 (1988) (agreeing with the Supreme Court that "the resolution of disputes [about the power of non-Article III tribunals] 'cannot turn on conclusory references to the lan- 
Columbia courts, courts-martial, the welfare state, and more. Claiming Chief Justice John Marshall as their vanguard, courts and commentators have sought to escape the constitutional text by drafting exceptions, striking balances, or proposing Pickwickian readings of Section 1 of Article III. ${ }^{2}$

This Article suggests that Section 1 of Article III does work, and that Chief Justice Marshall was the vanguard not for escaping the text, but for reading it carefully. Section 1 does not threaten life as we know it in the United States, nor does it threaten even most of the developments thought to run afoul of the Section. Read carefully, Section 1 does provide principled answers for some troublesome questions.

\section{A. Some Troublesome Questions}

Article III, Section 1 of the United States Constitution vests the federal judicial power in the federal courts and protects the tenure and compensation of the judges of those courts. As the Framers of the Constitution explained, an independent judiciary is a bulwark of freedom. ${ }^{3}$ Furthermore, the states were already chary of the power of the federal courts, ${ }^{4}$ and would have been all the more so if the federal

guage of Article III'" (quoting Commodity Futures Trading Comm'n v. Schor, 478 U.S. 833, 847 (1986))); Peter L. Strauss, Formal and Functional Approaches to Separation-ofPowers Questions-A Foolish Inconsistency?, 72 CORNELL L. REV. 488, 526 (1987) (advocating a functional approach to separation-of-powers issues because formalism "is simply incapable of describing the government we have"); Gordon G. Young, Public Rights and the Federal Judicial Power: From Murray's Lessee Through Crowell to Schor, 35 BUFF. L. REV. 765, 865 (1986) (suggesting that the "constitutional 'symbol' [of Article III] has been so changed that it bears no resemblance to its former self").

${ }^{2}$ For a brief review of germane precedent as "a number of highly questionable decisions impairing the protections afforded by [A] rticle III," see David P. Currie, Bankruptcy Judges and the Independent Judiciary, 16 CREIGHTON L. REV. 441, 445 (1983).

${ }^{3}$ See, e.g., THE FEDERALIST No. 47, at 301 (James Madison) (Clinton Rossiter ed., 1961) ("The accumulation of all powers, legislative, executive, and judiciary, in the same hands ... may justly be pronounced the very definition of tyranny."); id. No. 78, at 466 (Alexander Hamilton) ("[L]iberty can have nothing to fear from the judiciary alone, but would have everything to fear from its union with either of the other departments ...."). Montesquieu had written that "there is no liberty, if the judiciary power be not separated from the legislative and executive." 1 CHARLES DE MONTESQUIEU, THE SPIRIT OF LAWS 152 (Thomas Nugent trans., Colonial Press 1900) (1748).

${ }^{4}$ It is only by virtue of compromise among the Framers that lower federal courts exist at all. See CHEMERINSKY, supra note $1, \S 1.1$, at 3-4 (noting that after the proposal to create lower courts was defeated, James Madison and James Wilson "suggested that the Constitution mandate the existence of the Supreme Court, but leave it up to Congress whether to create inferior federal courts"). 
courts had been subservient to the President or Congress. ${ }^{5}$ Consequently, one might conclude that any federal adjudication must be within the exclusive province of judges with Section 1 security-that is, security from a cut in pay and from removal during good behavior.

From the earliest days of the nation, however, some federal judging has been performed by those without Section 1 security. The First Congress itself entrusted disputes regarding veterans' benefits, customs duties, and matters before courts-martial to determination by those who were themselves not judges at all. ${ }^{6}$ An 1828 opinion by Chief Justice John Marshall for the Court-his "vanguard" effortapproved a court established by Congress for the United States territory of Florida presided over by judges without Section 1 security. ${ }^{7}$ Likewise, in the landmark 1856 case of Murray's Lessee $v$. Hoboken Land $\mathcal{E}^{2}$ Improvement Co., the Court held that Congress may authorize executive officers-not judges in the least-to determine

matters, involving public rights, which may be presented in such form that the judicial power is capable of acting on them, and which are susceptible of judicial determination, but which congress may or may not bring within the cognizance of the courts of the United States, as it may deem proper. ${ }^{8}$

Two years after Murray's Lessee, in Dynes v. Hoover, the Supreme Court rebuffed a constitutional attack on courts-martial, the judges of which have no Section 1 security.

The twentieth century has seen the Court allow still more federal adjudication by those without Section 1 security. In the seminal case

5 To support the claim that King George engaged in "repeated injuries and usurpations" to establish "an absolute tyranny" over the American colonies, the Declaration of Independence charged that: "He has made judges dependent on his will alone, for the tenure of their offices, and the amount and payment of their salaries." THE DECLARATION OF INDEPENDENCE para. 9 (U.S. 1776); see also THE FEDERALIST NO. 78, supra note 3, at 465-66 (assuring that the standard of good behavior for federal judges would facilitate their independence from the legislative and executive branches).

${ }^{6}$ See Fallon, supra note 1, at 919-20 (noting that the First Congress delegated public-rights disputes to nonjudicial resolution and authorized military tribunals).

7 See American Ins. Co. v. Canter, 26 U.S. 511, 1 Pet. 388 (1828).

${ }^{8} 59$ U.S. (18 How.) 272, 284 (1856) (approving a levy on the land of a delinquent customs officer, though the levy was pursuant to a warrant issued by the solicitor of the treasury department, and not pursuant to the judgment of a court).

${ }^{9} 61$ U.S. (20 How.) 65, 78-79 (1858) (holding that congressional power to establish rules for trial and punishment of military offenses is "entirely independent" of Article III constraints, though the question of Section 1 security was not directly before the Court). 
of Crowell $v$. Benson, the Court held that deputy commissioners without Section 1 security could decide maritime disputes among private parties if judges with this security had appropriate power to review the decision. ${ }^{10}$ Such decisions were the work of "adjuncts" to the judges with Section 1 security, and not the work of full-fledged judges exercising full-fledged judicial power." This "adjunct" theory proved useful to later Courts that permitted federal magistrates to decide pretrial motions ${ }^{12}$ and preside over jury selection with the consent of the parties. ${ }^{13}$ After a brief formalist foray in Northerm Pipeline Construction Co. v. Marathon Pipe Line Co., ${ }^{14}$ the Court rested upon a balancing test that seems to give Congress substantial liberty to commit judicial power to officers without Section 1 security. ${ }^{15}$

${ }^{10} 285$ U.S. 22, $48-54$ (1932).

11 See id. at 54 (upholding the authority of the deputy commissioner and analogizing his function as factfinder to the familiar practice of appointing judicial "adjuncts" to determine amounts of damages in civil cases).

${ }_{12}$ See United States v. Raddatz, 447 U.S. 667, 680-81 (1980).

13 See Peretz v. United States, 501 U.S. 923, 940 (1991). For a review of cases regarding the constitutional limits of federal magistrate authority, see $A$ Constitutional Analysis of Magistrate Judge Authority, 150 F.R.D. 247 (1993) [hereinafter Constitutional Analysis].

${ }^{14} 458$ U.S. 50, 87 (1982) (plurality opinion) (holding unconstitutional the grant of power to bankruptcy courts to enter final judgment on a claim for damages for breach of contract). The claim was brought by a petitioner for reorganization before a bankruptcy judge without Section I security. An opinion by Justice Brennan for the plurality explained that precedent supported: (1) three narrow categories of legislative courts-territorial courts, courts-martial, and tribunals deciding public rights; and (2) the use of "adjuncts" to Article III courts, especially to assist in deciding matters regarding federal statutory rights when "the essential attributes of the judicial power are retained in the Article III court." Id. at 76-78 (plurality opinion). The bankruptcy judge fit none of these precedents. See id. at 87 . For an analysis that anticipated Justice Brennan's Northern Pipeline analysis, see Thomas G. Krattenmaker, Article III and Judicial Independence: Why the New Bankruptcy Courts Are Unconstitutional, 70 GEO. L.J. 297 (1981). Two Justices concurred in the judgment. A dissenting opinion by Justice White presaged the later balancing test after documenting the apparent doctrinal disarray of the Court's efforts in this area. See Northern Pipeline, 458 U.S. at 92-118 (White, J., dissenting).

${ }^{15}$ See Commodity Futures Trading Comm'n v. Schor, 478 U.S. 833, 857 (1986) (upholding the power of judges without Section 1 security to adjudicate state-law counterclaims arising out of the same transaction as the claim that the judge had statutory authority to decide); Thomas v. Union Carbide Agric. Prods. Co., 473 U.S. 568,592 (1985) (holding that Congress has the authority to select binding arbitration before an arbitrator without Section 1 security as a method of resolving disputes under administrative law). 
Each of these "several exceptions to article III's apparently clear command" presents a similar set of troublesome questions: Is the Constitution to govern this area of the law? If so, how to justify exceptions? What principles delimit exceptions once the constitutional text is left behind? ${ }^{17}$

\section{B. The Next Best Constitution}

Scholars and jurists have proposed diverse theories to justify and shape exceptions to the text of Section 1 . One theory is that necessity and history have created a set of exceptions-a "neo-Darwinian"18 theory that fails to explain why the march of necessity and history should halt with the present set. ${ }^{19}$ Another is that Article III is satisfied by appropriate review before judges with Section 1 security. ${ }^{20}$ This theory is difficult to square with the explicit provision of the Article that "Judges, both of the supreme and inferior Courts," shall have Section 1 security. ${ }^{22}$ The theory most popular these days, espe-

${ }^{16}$ Saphire \& Solimine, supra note 1, at 89; see also Deborah A. Geier, The Tax Court, Article III, and the Proposal Advanced by the Federal Courts Study Committee: A Study in Applied Constitutional Theory, 76 CORNELI L. REV. 985, 1003 (1991) (describing territorial courts, courts-martial, and public-rights cases as "historical exceptions" to the Constitution).

${ }^{17}$ Cf. Paul M. Bator, The Constitution as Architecture: Legislative and Administrative Courts Under Article III, 65 IND. L.J. 233, 246 (1990) ("Indeed, it is my own sense that this is a field in which any exception destroys the underlying rule.").

${ }^{18}$ Id. at 233.

19 And query: Just how necessitous is the necessity behind the exceptions? See, e.g., Frank H. Easterbrook, "Success" and the Judicial Power, 65 IND. L.J. 277, 278-80 (1990) (questioning the common reasons given for why a system involving life-tenured administrative law judges is undesirable).

${ }^{20}$ See Bator, supra note 17, at 266-70 (arguing that Article III is satisfied so long as judges with Section 1 security retain "ultimate judicial control"); Fallon, supra note 1, at 933 (opining that a "sufficiently searching review of a legislative court's or administrative agency's decisions by a constitutional court will always satisfy the requirements of Article III"); Saphire \& Solimine, supra note 1, at 135-52 (arguing that the availability and scope of review by an Article III court should be considered in assessing the authority of judges without Section 1 security).

${ }^{21}$ U.S. CONST. art. III, $\$ 1$ (emphasis added).

${ }_{22}$ See Northern Pipeline Constr. Co. v. Marathon Pipe Line Co., 458 U.S. 50, 86 n.39 (1982) (plurality opinion) (stating that "the constitutional requirements for the exercise of the judicial power must be met at all stages of adjudication," not just at the appellate level); see also Will v. Calvert Fire Ins. Co., 437 U.S. 655, 67476 (1978) (Brennan, J., dissenting) (arguing that state-court factual determinations regarding claims within the exclusive jurisdiction of the federal courts should not be given collateral estoppel effect in subsequent federal-court actions); England v. Louisiana State Bd. of Med. Exam'rs, 375 U.S. 411, 415-17 (1964) (Brennan, J.) (emphasizing the significance of conducting trial in federal court, notwithstanding the availability of ap- 
cially with the Court, ${ }^{23}$ is balancing. In one pan of the balance is the cost to Article III values, sometimes bifurcated into (1) a decrease in the protection of litigants from bias (a protection they are free to waive); and (2) a decrease in the protection of courts from breaches of the separation of powers. In the other pan is the advancement of Article I values, specifically that Congress exercise power as necessary to legislate effectively toward constitutional ends. ${ }^{24}$ If the benefits of

peal from other fora to the Supreme Court); cf. David A. Strauss, Article III Courts and the Constitutional Structure, 65 IND. L.J. 307, 309-10 (1990) (arguing that the core purpose of Section 1 security is the guarantee of the impartial decision of specific cases, not merely judicial review of issues of law).

${ }^{23}$ See, e.g., Commodity Futures Trading Comm'n v. Schor, 478 U.S. 833, 855 (1986) (upholding CFTC's delegated authority to adjudicate counterclaims in the situation where "separation of powers concerns are diminished"); Thomas v. Union Carbide Agric. Prods. Co., 473 U.S. 568, 592-94 (1985) ("Congress ... may create a seemingly 'private' right that is so closely integrated into a public regulatory scheme as to be a matter appropriate for agency resolution with limited involvement by the Article III judiciary. To hold otherwise would be to erect a rigid and formalistic restraint ....").

${ }^{24}$ This balancing is necessarily skewed: " [A]n immediately recognizable, concrete interest is balanced against an interest wholly prophylactic in nature, and therefore one whose benefits will never be immediately recognizable." Martin H. Redish, Legislative Courts, Administrative Agencies, and the Northern Pipeline Decision, 1983 DUKE L.J. 197, 221-22. Justice Brennan echoed this sentiment in his Schordissent. See 478 U.S. at 863 (Brennan, J., dissenting) ("[T]he Court pits an interest the benefits of which are immediate, concrete, and easily understood against one, the benefits of which are almost entirely prophylactic, and thus often seem remote and not worth the cost in any single case."). Professor Paul Bator, while granting Congress great discretion in establishing Article I adjudication, nevertheless found a balancing test unprincipled. See Bator, supra note 17 , at $257-58$ ("Balancing' ... seems to me to paper over the realities; it serves to provide a rather illusory band-aid for the wounds inflicted on the Simple Model."). Also, Professor Daniel Meltzer warned of the incremental erosion of Article III by measures that individually appear safe. See Daniel J. Meltzer, Legislative Courts, Legislative Power, and the Constitution, 65 IND. L.J. 291, 292 (1990) ("I suspect that judicial independence is less likely to be subverted by "wholesale transfers of jurisdiction' or by a Congress with destructive intent than by the accretion of measures, each of which creates a significant jurisdiction in a non-article III tribunal." (quoting Bator, supra note 17, at 258)). The example given by the Schor Court of what might tip the balance to an unconstitutional extreme offers no comfort:

[I]f Congress created a phalanx of non-Article III tribunals equipped to handle the entire business of the Article III courts without any Article III supervision or control and without evidence of valid and specific legislative necessities, the fact that the parties had the election to proceed in their forum of choice would [not] necessarily save the scheme from constitutional attack.

478 U.S. at 855 . Saphire and Solimine find the implications of this passage "potentially significant, if not staggering." Saphire \& Solimine, supra note 1, at 121.

Apparently, the federal bench is not willing to protect its own jurisdiction from diminution. As long as the "important" cases remain before federal judges, they seem willing to lose the common-law contract claim (Schor) and the run-of-the-mill federal statutory commercial claim (Thomas). In fact, they may perceive the mass of such "unimportant" claims as crowding out important cases. In such circumstances, the 
the advancement of Article I values outweigh the costs to Article III values, then the "exception" to Article III passes constitutional muster before the Court. This balancing theory, at least, makes explicit the notion that necessity fuels the engine of exceptions to the constitutional text. ${ }^{25}$

One would think that embracing this balancing theory would doom the exceptions. The text of the Constitution already has balanced Article III values against Article I values. Indeed, that balance is the very object of the text. The text invites a rebalancing only in Article V, concerning constitutional amendment. Furthermore, only a centralizing, nationalistic pragmatism argues that Article I necessitates departure from Article III. Why not argue that Article III necessitates a departure from Article I ${ }^{26}$ Regardless, both arguments err in positing a defect in the text. Would not faithfulness to the Constitution counsel, rather, that Article I values, like Article III values, are to be pursued to the extent and in the manner prescribed by the Constitution itself? The text itself indicates that in crafting Article III, the Framers limited the powers of Congress. ${ }^{27}$ How, then, is it possible

checks and balances of the Constitution will fail, see THE FEDERALIST NO. 51 (James Madison), because the personal ambitions of judges will have diverged from those of their office, presuming, of course, that the office does embrace deciding such "unimportant" claims. What's a Constitution among friends?

${ }_{25}$ Even before Thomas and Schor, a perceptive student had noted:

Article III's tenure and salary provisions were meant to insulate the adjudicatory process from the influence of the political branches. Yet the principle of judicial independence has gradually been limited by the Court in response to the evolving necessities of the modern administrative state. Although this evolution may be unavoidable and beneficial, the Court's decisions regarding legislative courts and adjuncts have gone too long without being anchored in a principled interpretation of article III.

Note, Federal Magistrates and the Principles of Article III, 97 HARV. L. REV. 1947, 1963 (1984).

${ }^{26}$ Cf. JOHn Milton, PARAdise LOST 96 (Merrut Y. Hughes ed., Odyssey Press 1962) (1674) ("So spake the Fiend, and with necessity,/The Tyrant's plea, excus'd his devilish deeds.").

${ }^{27}$ As the staff of the Senate Subcommittee on Improvements in Judicial Machinery noted in 1967:

The argument that Congress' [s] power to legislate generally for [federal] enclaves includes the power to provide for the enforcement of such legislation by non-Article III officials is, at least, suspect. Congress has exclusive jurisdiction over the coinage of money and the punishment of counterfeiters, U.S. CONST., art. I, $\S 8, \mathrm{cl} .5,6$; id art. I, $\$ 10$, but these provisions do not give it power to provide for the trial of counterfeiters without regard to the limitations of Article III. Congress has the power to promote the "Progress of Science and useful Arts" by enacting appropriate patent and copyright laws, U.S. CONST., art. I, $\S 8$, cl. 8, but that provision does not mean then Congress can insulate all cases and controversies involving the patent and copyright laws 
that the Constitution requires that a constitutional "value" exceed its constitutional bounds?

\section{A Constitutional Trial}

Until it embraced a balancing test in Thomas v. Union Carbide Agricultural Products $\mathrm{Co}^{28}$ and Commodity Futures Trading Commission v. Schor, ${ }^{29}$ the Supreme Court never passed off the "exceptions" to Section 1 as exceptions. One must wonder whether the likes of John Marshall would have carved out an exception to Section 1 security so as to enhance congressional prerogatives at the expense of the federal judiciary. ${ }^{30}$ Rather, as we shall see, the classic "exceptions" opinions read as expositions of Section 1, not evasions.

This Article aspires to follow in the tradition of those classic opinions. It suggests that Section 1 invites careful reading, not evasion by exceptions spawned by "[t]he felt necessities of the time." ${ }^{31}$ It assumes that the text of the Constitution is constitutional law. ${ }^{32}$ Treated

from the requirements of Article III, and have them resolved in special proceedings that do not involve the judicial power of the United States. Congress has the power to regulate interstate and foreign commerce, U.S. CONST., art. I, $\S 8, \mathrm{cl} .3$, and punish certain acts that jeopardize such commerce, U.S. CONST., art. I, $\S 8$, cl. 18 , but this does not mean that Congress can provide that all violations of penal laws passed pursuant to the commerce power must be prosecuted in a special "commerce court" that is insulated from the provisions of Article III. The mere fact that a particular law finds its constitutional roots in an Article I power, such as the authority to regulate Federal enclaves, does not give it any special status when viewed against the requirements that Article III sets down for the trial of all "cases and controversies."

Federal Magistrates Act, 1967: Hearings on S. 945 Before the Subcomm. on Improvements in Judicial Mach. of the Senate Comm. on the Judiciary, 90th Cong. 250 (1967) (memorandum prepared by the staff of the Subcommittee on Improvements in Judicial Machinery).

473 U.S. $568,582-86$ (1985).

29478 U.S. 833,851 (1986) (balancing, among other factors, "the concerns that drove Congress to depart from the requirements of Article III" (emphasis added)).

${ }^{30}$ One must wonder further about Marshall if the carving out of exceptions to Section 1 security was to enhance the prerogatives of the Jacksonian Congress. See AVERY CRAVEN \& WALTER JOHNSON, THE UNITED STATES: EXPERIMENT IN DEMOCRACY 299 (1947) (noting the rift between Marshall on the one hand, and Jackson and the House of Representatives on the other, regarding Worcester $v$. Georgia, 31 U.S. (6 Pet.) 515 (1832): "John Marshall has made his decision; now let him enforce it.").

${ }^{31}$ OLIVER WENDELl HOLMES, JR., THE COMMON LAW 1 (Boston, Little, Brown, and Co. 1881).

${ }^{32}$ For a similar approach regarding interpretations of the Eleventh Amendment, see Lawrence C. Marshall, Fighting the Words of the Eleventh Amendment, 102 HARV. L. REV. 1342 (1989). Professor Marshall challenges originalist interpreters of the Eleventh Amendment "who claim to justify their approach as based on original intent but, 
with respect, Section 1 comprises a principled, workable algorithm for determining what matters must come before judges with Section 1 security. The algorithm needs no exceptions, and brooks none. Still less does it need supplanting with unprincipled ipse dixit-balancing. ${ }^{39}$

The rest of this Article comprises three major Parts, each of which examines a different component of the text of Section 1. Part II examines "the judicial Power." Distinguishing between the judicial and the executive powers resolves two important problems thought to require exceptions to the text: problems raised by courts-martial and the public-rights doctrine. Part III examines the judicial power "of the United States." A proper appreciation of this language resolves another important problem, that raised by territorial courts. Part IV-resolving yet a fourth problem (that of the "adjunct" theory)examines the vesting of federal judicial power in "Courts," the "Judges" of which have Section 1 security. Each of the three components embraces a principle for our Constitution. Each also marks a practical limit to the requirement of Section 1 security. Adhering to the text of Article III should lend coherence to a jurisprudence in disarray, ${ }^{34}$ a coherence born of the Constitution itself and the principles that animate it.

at the same time, ignore the best possible evidence of that intent-the precise and determinate words of the amendment." Id. at 1345. Placing the text in its historical and original legal context, Marshall "show[s] that there are... explanations for why the amendment reads as it does, and that there is, therefore, no justification for discarding the plain meaning of the text. $I d$. at 1371. Similarly, this Article embraces a textualism that strives to understand the constitutional text in its historical and original legal context.

${ }^{39}$ See Bendix Autolite Corp. v. Midwesco Enters., Inc., 486 U.S. 888, $895-98$ (1988) (Scalia, J., concurring in judgment) (criticizing balancing analyses); Antonin Scalia, The Rule of Law as a Law of Rules, 56 U. CHI. L. REV. 1175, 1186 (1989) (arguing that "when balancing is the mode of analysis, not much general guidance may be drawn from the opinion").

${ }^{34}$ Chief Justice Rehnquist's concurring opinion in Northern Pipeline expressed his doubt as to "whether [the precedents in this area] in fact support a general proposition and three tidy exceptions, as the [Brennan plurality opinion had held], or whether instead they are but landmarks on a judicial 'darkling plain' where ignorant armies have clashed by night, as Justice White apparently believes them to be [as described in his dissenting opinion advocating balancing]." Northern Pipeline Constr. Co. v. Marathon Pipe Line Co., 458 U.S. 50, 91 (1982) (Rehnquist, J., concurring in judgment). Typical seems to be the view that "[j]udicial analysis in this area... is veiled by layer upon layer of dubiety," Geier, supra note 16, at 1033, and that the Court's efforts in Northern Pipeline, Thomas, and Schor left "muddy waters" "even muddier," id. at 1002. 


\section{COURTS-MARTIAL, PUblic Rights, AND THE JUdicial POWER}

\section{A. Courts-Martial and "the Judicial Power"}

From the earliest days, courts-martial have not employed judges with Section 1 security. Almost as old as this practice is the doctrine that agencies of the federal government may decide matters of public rights without the ministrations of judges with Section 1 security. Although the Supreme Court has cast these two phenomena as historic exceptions to the terms of Article III, ${ }^{35}$ they actually illustrate the textual limits of that Article. Article III purports to describe and vest only "the judicial Power." Conducting courts-martial and deciding matters of public rights are matters of executive, not judicial, power. Consequently, Article III and its Section 1 security have nothing to do with them.

It is commonly remarked that the judicial power involves applying law to facts, and so it does. But this description is incomplete. My thirteen-year-old son had better apply law to facts when he rides his bicycle, yet that is not to ask him to exercise the judicial power. The late Professor Paul Bator noted that the executive must often apply law to facts. ${ }^{37}$ What makes applying law to facts an exercise of the judicial power is the nature and purpose of that application. If it is done by a boy to guide his bike, it is not an exercise of the judicial power. If it is done by an executive agency to guide its actions, it is not an exercise of the judicial power. ${ }^{38}$ If, however, it is done for op-

${ }^{35}$ See, e.g., Nonthern Pipeline, 458 U.S. at 63-70, 70 (plurality opinion) (identifying "three situations [courts-martial, cases dealing with "public rights," and territorial courts] in which Article III does not bar the creation of legislative courts" and noting that "[i]n each of these situations, the Court has recognized certain exceptional powers bestowed upon Congress by the Constitution or by historical consensus").

${ }^{36}$ U.S. CONST. art. III, $\$ 1$ (emphasis added).

${ }^{37}$ See Bator, supra note 17, at 264 ("Every time an official of the executive branch, in determining how faithfully to execute the laws, goes through the process of finding facts and determining the meaning and application of the relevant law, he is doing something which functionally is akin to the exercise of judicial power."). Bator, however, used this observation to pan the very notion that the judicial power is essentially distinct from executive power, and should be vested in Article III courts alone. See id. at 265 ( ' $[\mathrm{I}] \mathrm{t}$ is philosophically muddled and institutionally chimerical to try to create a rigid logical scheme to define what 'is' the exercise of the federal judicial power and then insist [] that the article III courts retain a monopoly over whatever "it' is.").

${ }^{38}$ This is no anomaly. Neither is it a breach of the separation of powers. Presidents issue executive orders, the Houses of Congress command Sergeants-at-Arms and Doorkeepers, federal courts promulgate local rules, and so on. What places these powers safely within a "noncorresponding" branch is the context and purpose of the power. Executive orders direct officers of the executive branch as to the will of the 
posing parties by a neutral with the purpose of authoritatively pronouncing the law in officially resolving a dispute between these opponents, then it is an exercise of the judicial power.

The concept of "the judicial Power" was well known to the Framers. The common law largely would have shaped the concept. ${ }^{39}$ And the common-law concept of the judicial power depended upon procedure, procedure that emphasized the role of parties-plaintiffs bringing actions and defendants answering them. ${ }^{40}$ To the same effect would have been the familiar locus classicus from Holy Writ, Moses' description to Jethro, his father-in-law, of his own role as judge: "When they have a matter, they come unto me; and I judge between one and another, and I do make them know the statutes of God, and his laws."

Chief Executive whom they assist. The Legislative Houses command their own officers in order to legislate more efficiently. Federal courts adopt rules to promote the just resolution of litigation before them. See, e.g., Chandler v. Judicial Council, 398 U.S. 74, $84-85$ (1970) ("Many courts-including federal courts-have informal, unpublished rules .... These are reasonable, proper and necessary rules."); Textile Mills Sec. Corp. v. Commissioner, 314 U.S. 326, 332 (1941) (noting the functions of the Supreme Court, other than those of an appellate tribunal, as provided for in the Judicial Code, include "prescribing the form of writs and other process and the form and style of its seal; the making of rules and regulations; the appointment of a clerk ... ; and the fixing of the 'times' when court shall be held" (citations omitted)); Wayman v. Southard, 23 U.S. I, 42, 10 Wheat. 1, 94-96 (1825) ("[C]ongress has expressly enabled the courts to regulate their practice by other laws .... [C] ongress may certainly delegate to others, powers which the legislature may rightfully exercise itself."). The test of appropriate power is not an arid exercise in formalism. Illumined by the constitutional text, the common law, and long-standing practice, the separation of powers distributes the three broad functions of the federal government. It does not banish from each branch operations appropriate and subservient to the function assigned it. See Harold J. Krent, Separating the Strands in Separation of Powers Controversies, 74 VA. L. REV. 1253, 1308 (1988) ("[J]udges ordinarily perform ... 'housekeeping' duties in their own interests, not at the behest of other branches. There is little dispute that the judiciary may discharge the administrative authority necessary to conduct its own business without running afoul of the separation of powers doctrine.").

${ }^{39}$ "The language of the Constitution cannot be interpreted safely except by reference to the common law and to British institutions as they were when the instrument was framed and adopted." Ex parte Grossman, 267 U.S. 87, $108-09$ (1925); see also U.S. v. Wong Kim Ark, 169 U.S. 649, 65455 (1898).

to See Harold J. BERMaN, LAw AND REvolution 451-53 (1983) (discussing the development and importance of the system of writs); LAWRENCE M. FRIEDMAN, A HISTORY OF AMERICAN LAW 49-51, 126-29 (1973) (discussing the influence of common law, including its reliance on parties, in the development of the early American law of civil procedure); THEODORE F.T. PLUCKNETT, A CONCISE HISTORY OF THE COMMON LAW 353-418 (1956) (surveying the development of the procedure of the common law).

${ }^{41}$ Exodus 18:16 (King James). Blackstone drew upon a related passage from chapter 18 of Exodus in discussing the structure of the English judicial system. See 3 
jus dicere, Latin for "to speak the law." The judicial power is an official "speaking of the law" to other parties so as to resolve a dispute between them. ${ }^{42}$

The Supreme Court had occasion in 1851 to consider the meaning of "the judicial Power." ${ }^{43}$ Congress had authorized judges to receive and adjust Spanish claims against the United States for its operations in Florida. The judges reported to the Secretary of the Treasury, who would pay if "satisfied" that the award was "just and equitable." ${ }^{\prime 4}$ The Court decided that it had no jurisdiction to hear an appeal from the judge's award because the award was not the product of a judicial function:

For there is to be no suit; no parties in the legal acceptance of the term, are to be made-no process to issue; and no one is authorized to appear on behalf of the United States, or to summon witnesses in the case. The proceeding is altogether ex parte; and all that the judge is required to do, is to receive the claim when the party presents it, and to adjust it upon such evidence as he may have before him, or be able himself to obtain. $^{45}$

Though "judicial in their nature" and entailing "judgment and discretion," the power of the judge to make an award and the power of the Secretary to pay it were "not judicial in either case, in the sense in which judicial power is granted by the Constitution to the courts of the United States." ${ }^{46}$ Therefore, appeal did not lie to the Supreme Court. This case illustrates that the "judicial nature" of decisionmaking does not suffice to render it an exercise of the judicial power.

WILLIAM BLACKSTONE, COMMENTARIES *31 ("[W] e read of Moses; that, finding the sole administration of justice too heavy for him, he 'chose able men out of all Israel, such as feared God, men of truth ... and made them head over the people, rulers of thousands, rulers of hundreds, rulers of fifties, and rulers of tens: and they judged the people at all seasons; the hard causes they brought unto Moses, but every small matter they judged themselves." (quoting Exodus 18:21-22)); see also BLACK's LAW DICTIONARY 849 (6th ed. 1990) ("Courts [as vested with judicial power] have general powers to decide and pronounce a judgment and carry it into effect between two persons and parties who bring a case before it for decision ...."); 1 MONTESQUIEU, supra note 3, at 151 ("By the [judiciary power, the prince or magistrate] punishes criminals, or determines the disputes that arise between individuals.").

${ }^{42}$ The notion of the judicial power as a power to be exercised by one not party to the dispute finds expression in the maxim, in propria causa nemo judex-no one is to be judge in his own case.

${ }^{43}$ United States v. Ferreira, 54 U.S. 39, 13 How. 43 (1851).

${ }^{44} I d$. at 45,13 How. at 49 .

45 Id. at 46, 13 How. at 50.

${ }^{46} I d$. at 48,13 How. at 53 
The context and purpose of the decision also bear upon the question. Without a suit, without "parties," the judicial power is absent."

Likewise, upon the force of this reasoning, courts-martial do not exercise the judicial power. Instead, they exercise the executive power, the power of a military command to discipline its troops. ${ }^{48}$ Dynes v. Hoover explained that the Constitution invests Congress with power to establish the military and, along with it, its customary usages and institutions. ${ }^{50}$ Courts-martial are part of the chain of command, an effective means of administering discipline that otherwise might be meted out by the commander himself. . $^{51}$ "In essence, these tribunals are simply executive tribunals whose personnel are in the executive chain of command. ${ }^{, 52}$ This fact explains why courts-martial are so different from civilian courts and why only military personnel are subject to their jurisdiction. ${ }^{53}$ As the Court stated in Dynes, the congres-

${ }^{47}$ But see Tutun v. United States, 270 U.S. 568, 577 (1926) (stating that naturalization in the district courts is within the judicial power, being "instituted and ... conducted throughout according to the regular course of judicial procedure.").

${ }^{49}$ See, e.g., O'Callahan v. Parker, 395 U.S. 258, 265 (1969) ("A court-martial is not yet an independent instrument of justice but remains to a significant degree a specialized part of the overall mechanism by which military discipline is preserved." (footnote omitted)), overruled on other grounds by Solorio v. United States, 483 U.S. 435 (1987); Reid v. Covert, 354 U.S. 1, 36 (1957) (describing military courts as "executive tribunals"); United States ex rel. Toth v. Quarles, 350 U.S. 11, 17, 22, 29, 41-43 (1955) (distinguishing military courts from civilian courts); David A. Schlueter, The CourtMartial: An Historical Survey, 87 MIL. L. REV. 129, 154-55 (1980) ("[T] he court-martial, at least to [1874], was considered primarily as a function or instrument of the executive department to be used in maintaining discipline in the armed forces. It was therefore not a 'court', as that term is normally used.").

${ }^{49} 61$ U.S. (20 How.) 65 (1857) (upholding the authority of a court-martial).

${ }^{50}$ The Dynes Court noted that the sentences of many courts-martial could not be executed unless confirmed by the President or Secretary of the Navy, "who ordered the court." Id. at 81 . The officer "ordering the court . . . is made by the law the arbiter of the legality and propriety of the court's sentence." Id. Similarly, the present Uniform Code of Military Justice grants to convening officials authority "to modify the findings and sentence of a court-martial [as] a matter of command prerogative involving the sole discretion of the convening [official]." 10 U.S.C. $\$ 860$ (c)(1) (1994).

${ }^{51}$ See Easterbrook, supra note 19, at 281 (noting that " $[\mathrm{m}]$ ilitary decisions ... stem from a tradition of summary punishment within the chain of command").

${ }^{52}$ Reid, 354 U.S. at 36.

${ }^{53}$ U.S. CONST. art. I, $\$ 8, \mathrm{cl}$. 14 (providing that Congress may "make Rules for the Government and Regulation of the land and naval Forces," presumably including the authorization of courts-martial (emphasis added)); see Reid, 354 U.S. at 34-37 (holding that an overseas civilian dependent of a serviceman, though residing on base, is beyond the jurisdiction of a court-martial trying a capital charge in time of peace); Toth, 350 U.S. at $22-23$ (holding that a discharged veteran is beyond the jurisdiction of a court-martial); Ex parte Milligan, 71 U.S. (4 Wall.) 2, 130 (1866) (holding that a citizen 
sional power to establish courts-martial "is given without any connection between it and the $3 \mathrm{~d}$ article of the Constitution defining the judicial Power of the United States; indeed, ... the two powers are entirely independent of each other., ${ }^{54}$

Again, the claim is not that courts-martial somehow are not courts, or that courts-martial somehow decide cases while avoiding "judicial" behavior. Long ago, the Supreme Court, in the context of a military tribunal, recognized that "[e]very trial involves the exercise of judicial power." ${ }^{, 55}$ (In the next sentence, however, the Court was quick to note that "[c]ertainly no part of the judicial power of the country was conferred on" the tribunal in the case.) ${ }^{56}$ Likewise, the Court has ruled that a nineteenth-century statute requires the President to act judicially when approving as commander-in-chief the sentence of a court-martial. ${ }^{57}$ These precedents, like the very use of the terms "court" and "judge" in military discipline, cast courts-martial and other authorities in judicial roles. ${ }^{58}$ No doubt, military discipline

with no connection to the military or to a rebellious state is beyond the jurisdiction of a "military commission").

${ }^{54} 61$ U.S. (20 How.) at 79; see also Currie, supra note 2, at 449 (noting the "historically special and separate position of military justice").

${ }^{55}$ Milligan, 71 U.S. (4 Wall.) at 121.

${ }^{56} I d$. (emphasis added).

${ }^{57}$ See Runkle v. United States, 122 U.S. 543, 557 (1887) ("Here ... the action required of the $[\mathrm{P}]$ resident is judicial in its character, not administrative.").

${ }_{53}$ And yet, Colonel William Winthrop, "the Blackstone of American military law" and chief exponent of "the classical theory of military law," Walter T. Cox, III, The Army, the Courts, and the Constitution: The Evolution of Military Justice, 118 MIL. L. REv. 1, 9 (1987), explained that "strictly, a court-martial is not a court in the full sense of the term, or as the same is understood in the civil phraseology." WILLIAM WINTHROP, MILITARY LAW AND PRECEDENTS 49 (2d rev. ed. 1920); see also GARRARD GLENN \& A. ARTHUR SCHILlER, THE ARMY AND THE LAW 51-52 (rev. ed. 1943) (noting that "[s] trictly speaking, a court-martial is not a court in the full sense of the term"). At the same time, however, Winthrop noted that the court-martial, "so far as it is a court at all, and within its field of action, [is] as fully a court of law and justice as is any civil tribunal." WiNTHROP, supra, at 54. The court-martial is bound by law, and must act without partiality and in accordance with justice. See id. A later authority would explain:

In the development of discipline, correction of individuals is indispensable; in correction, fairness or justice is indispensable. Thus, it is a mistake to talk of balancing discipline and justice-the two are inseparable. An unfair or unjust correction never promotes the development of discipline. As stated in our preliminary report, "All correction must be fair; both officers and soldiers must believe that it is fair."

... It is not proper to say that a military court-martial has a dual function as an instrument of discipline and as an instrument of justice. It is an instrument of justice and in fulfilling this function it will promote discipline. 
entails the application of law to facts, making use of the judicial method. Nevertheless, the context of that method is not that of "the judicial Power" as that term is used in Article III. It is not to resolve a dispute, but rather to arrive at an appropriate discipline for the command to impose, albeit a discipline that is according to law and justice.

A recent case dealing with the legal status of military judges gave the Supreme Court opportunity to reaffirm the difference between the power of courts-martial and "the judicial Power" of Article III. . $^{59}$ Two Marines received convictions and sentences from courts-martial. They attacked these decisions on two theories: First, that the Appointments Clause of the Constitution required an appointment of military judges separate from their appointment as military officers; and second, that the Due Process Clause required fixed terms for military judges. The Court rejected both theories. It rejected the first, in part, because military judges had already been appointed as military officers. Beyond this, "all military officers, consistent with a long tradition, play a role in the operation of the military justice system." ${ }^{60}$ Officers impose discipline, serve as members of courts-martial (including some courts-martial that have no judge whatsoever), and may modify the sentences of courts-martial. "By the same token, the position of military judge is less distinct from other military positions than the office of full-time civilian judge is from other offices in civilian society." ${ }^{, 61}$ The military judge is more an officer detailed for a particular special duty than an officer whose standing sets him apart as one requiring a separate appointment.

The second theory of the petitioners, based upon the Due Process Clause, fell before two main objections. The petitioners conceded that military judges, as Article I judges, need not receive the goodbehavior tenure secured by Article III. The petitioners did argue, however, that the Due Process Clause of the Fifth Amendment required that military judges receive some fixed term of office. The

COMMITTEE ON THE UNIF. CODE OF MILITARY JUSTICE GOOD ORDER AND DISCIPLINE IN THE ARMY, REPORT TO HONORABLE WILBER M. BRUCKER, SECRETARY OF THEARMY 11-12 (1960). That effective instruments of military discipline must apply law justly and even adopt the techniques of courts does not render them instruments of the judicial power. They remain instruments of the executive. Does any other executive official work a translation into the judicial branch by applying law justly to controversial facts carefully adduced?

\footnotetext{
59 See Weiss v. United States, 510 U.S. 163 (1994).

${ }^{60} I d$. at 175.

${ }^{61}$ Id.
} 
Court disagreed. The Court first noted that the Anglo-American tradition of military justice had never granted military judges a fixed term of office. Courts-martial were long presided over by officers as part of their general duties. "Courts-martial ... have been conducted in this country for over 200 years without the presence of a tenured judge, and for over 150 years without the presence of any judge at all. ${ }^{62}$ Second, the Court explained that recent efforts by Congress to promote the fairness of courts-martial, efforts that to some degree had moved the system of military justice closer to the civilian system, sufficed to provide due process.

In deciding this case, the Supreme Court once again has cast courts-martial as institutions exercising something other than "the judicial Power." The Constitution requires neither that military judges receive separate appointments nor that they receive a fixed term of tenure. For all that appears, the Constitution does not require that courts-martial include judges at all. These conclusions follow from the proposition that courts-martial are instruments of discipline, inhouse-almost advisory-committees to determine how the armed forces should take care of their own. They are to be just in applying law to fact. They are attended by dignity and formality. Yet, ultimately, they are not established to do justice between suitors. ${ }^{64}$

${ }^{62}$ Id. at 179.

${ }^{63}$ See id. at 179-81 (noting provisions of the Uniform Code of Military Justice that "sufficiently preserve judicial impartiality so as to satisfy the Due Process Clause").

${ }^{64}$ The Weiss Court noted a question not at issue in the case but pertinent to the argument of this Article. The highest military court is the Court of Military Appeals, a court "of five civilian judges who are appointed by the President, with the advice and consent of the Senate, for fixed terms of 15 years." Id. at 169. The tenure of its judges-a matter the Court remarked was not at issue in the case before it-would suggest that Congress considered it to be an Article I, not an Article III, court. Nevertheless, the Military Justice Act of 1983 allows review by the United States Supreme Court on a writ of certiorari to the Court of Military Appeals. 28 U.S.C. $\$ 1259$ (1994); see also Bennett Boskey \& Eugene Grossman, The Supreme Court's New Certiorari Jurisdiction over Military Appeals, 102 F.R.D. 329, 331 (1985) (listing the types of cases in which the Supreme Court may review the decisions of the Court of Military Appeals). If the Court of Military Appeals is an Article I court by analogy to courts-martial, it is an Article I court because it exercises no part of the judicial power as that concept is embraced by Article III. But, if so, how may the Supreme Court review that court's decisions? Such power is not within the Supreme Court's original jurisdiction. See U.S. CONST. art. III, § 2. Perhaps it also is not within the Supreme Court's appellate jurisdiction if the Court of Military Appeals, for lack of the judicial power, is incapable of conducting proceedings that truly are judicial. Cf. Marbury v. Madison, 5 U.S. (1 Cranch) 137,175 (1803) ("It is the essential criterion of appellate jurisdiction that it revises and corrects the proceedings in a cause already instituted...."). 
The Fifth and Sixth Amendments reflect the understanding that courts-martial do not exercise the judicial power. The Fifth Amendment begins, "[n]o person shall be held to answer for a capital, or otherwise infamous crime, unless on a presentment or indictment of a Grand Jury, except in cases arising in the land or naval forces." This text seems designed to exclude matters before courts-martial from the requirements of this clause, at least. ${ }^{66}$ The Sixth Amendment mentions no such exception, but instead begins, " $[\mathrm{i}] \mathrm{n}$ all criminal prosecutions, the accused shall enjoy the right to a speedy and public trial." ${ }^{67}$ Yet the Court has rightly concluded that the Sixth Amendment, like the presentment clause of the Fifth Amendment, does not apply to military tribunals. ${ }^{68}$ The Sixth Amendment therefore suggests that proceedings in courts-martial are not "criminal prosecutions"; indeed, they are not. ${ }^{69}$ Soldiers are "held to answer" for breaches of discipline before courts-martial, but are not thereby the subjects of "criminal prosecutions." They are, rather, subjects of executive discipline.

Courts-martial are not "exceptions" to Article III. ${ }^{70}$ Nor is placing them outside the Article an act of nominalism or legerdemain. However disinterested and fair, courts-martial are instruments of military discipline, not instruments of adjudication by a neutral institution. "The judicial Power" vested by Article III embraces the latter, but not the former. The benefits of Section 1 security, even if helpful for this executive function, might be bought too dearly if military officers had to be invested with it before they could judge in a court-martial.

${ }^{65}$ U.S. CONST. amend. V.

${ }^{66}$ See United States ex rel. Toth v. Quarles, 350 U.S. 11, 14 n.5 (1955) (noting that the Fifth Amendment "makes clear that there need be no indictment for such military offenses as Congress can authorize military tribunals to try"). The Court has stated, however, that the Due Process Clause of the Fifth Amendment does apply to courtsmartial. See Middendorf v. Henry, 425 U.S. 25, 43 (1976) (stating that a party due to appear before a court martial is entitled to the Fifth Amendment guarantee of due process of law).

${ }^{67}$ U.S. CONST. amend. VI.

${ }^{6 s}$ See Ex parte Milligan, 71 U.S. (4 Wall.) 2, 123-24 (1866) (observing that the Sixth Amendment applies only "to those persons who were subject to indictment or presentment" in the fifth Amendment).

${ }^{69}$ The Middendorf Court held that a summary court-martial was not a "criminal prosecution" within the meaning of the Sixth Amendment. See 425 U.S. at 33-42.

${ }^{70}$ But see Northern Pipeline Constr. Co. v. Marathon Pipe Line Co., 458 U.S. 50, $71-72$ (1982) (plurality opinion) (suggesting that courts-martial are an exception). 


\section{B. Public Rights and the Judicial Power}

The public-rights doctrine derives from applying the above principle to other executive agencies, which, like courts-martial, may make decisions without exercising the judicial power. This doctrine permits executive agents without Section 1 security to decide certain disputes between private parties and the federal government, disputes embracing claims either of private parties against the government, or of the government against private parties. ${ }^{71}$ One would hope that all executive agencies-obliged, at least indirectly, to "take Care that the Laws be faithfully executed"72-would apply the law to facts in performing their duties. Yet here too, the end of applying law to facts is not authoritatively to pronounce the law in resolving disputes between others. It is to perform the duties of administration and execution. Deciding whom to prosecute, what taxes to assess, what grants to disburse, which veterans qualify for benefits-these, and perhaps most, decisions of the executive require applying the law to facts. They are not, however, instances of "the judicial Power."

Murray's Lessee v. Hoboken Land EN Improvement Co., ${ }^{74}$ the fountainhead of the public-rights doctrine, explains as much. That case tested title to lands once held by an absconding collector of customs. One party claimed that title had passed under a distress warrant issued by a treasury department official. The other party claimed that the warrant took property without due process because an executive officer could not perform the judicial act of issuing the warrant. Both Article III and the Fifth Amendment, this party asserted, required that such a

${ }^{71}$ See CHEMERINSKY, supra note $1, \S 4.4$, at $219-20$ (discussing the ability of legislative courts to hear public-rights cases).

72 U.S. CONST. art. II, § 3.

${ }^{79}$ Professor Bator asserts that these are exercises of the judicial power, an assessment that leads him to argue that the judicial power is not categorically different from the executive power. See Bator, supra note 17, at 264-65 (finding an overlap of executive, judicial, and legislative powers). The following assessment should be enough to defeat his analysis. The Constitution indicates that the executive and the judicial powers are distinct. Compare U.S. CONST. art. II, $\S 1$ ("The executive Power shall be vested in a President of the United States of America."), with U.S. CONST. art. III, § 1 ("The judicial Power of the United States, shall be vested in one supreme Court, and in such inferior Courts as the Congress may from time to time ordain and establish."). One's understanding of these powers ought to reflect at least this much. The understanding that does reflect this distinction realizes that it is not only the act of applying law to facts that constitutes the judicial power, but also the context and purpose of that act. See supra text accompanying notes $37-42$.

${ }^{74} 59$ U.S. (18 How.) 272 (1856). 
warrant issue from a court of law. And if the matter were not one for the judicial power, how could a court be hearing the case? ? $^{75}$

The Court replied:

That the auditing of the accounts of a receiver of public moneys may be, in an enlarged sense, a judicial act, must be admitted. So are all those administrative duties the performance of which involves an inquiry into the existence of facts and the application to them of rules of law. In this sense the act of the President in calling out the militia under the act of 1795, or of a commissioner who makes a certificate for the extradition of a criminal, under a treaty, is judicial. But it is not sufficient to bring such matters under the judicial power, that they involve the exercise of judgment upon law and fact. It is necessary to go further, and show not only that the adjustment of the balances due from accounting officers may be, but from their nature must be, controversies to which the United States is a party, within the meaning of the second section of the third article of the constitution. We do not doubt the power of congress to provide by law that such a question shall form the subject-matter of a suit in which the judicial power can be exerted. The act of 1820 makes such a provision for reviewing the decision of the accounting officers of the treasury. But, until reviewed, it is final and binding; and the question is, whether its subject-matter is necessarily, and without regard to the consent of congress, a judicial controversy. And we are of opinion it is not. ${ }^{76}$

The Court explained that, just as a private creditor has at its disposal means of self-help, so too does the federal government. Longstanding English, state, and federal practice recognized the right of the executive to gather sums owing from a tax collector, even by seizing his property or person. Although Congress may provide for judicial remedies to test such seizures, the nature of the distress warrant in Murray's Lessee was executive. The warrant's purpose was not to award property to one of two parties contesting rights before a tribunal. It was to manage federal tax revenue. Only if Congress submitted the executive to the federal courts to test the warrant would the judicial power obtain, for then a tribunal would indeed be called upon to pronounce the law in order to resolve a dispute between two contestants.

75 See id. at 282 (noting that a party's "argument is, that if this were not, in its nature, a judicial controversy, congress could not have conferred on the district court power to determine it upon a bill filed by the collector").

${ }_{77}^{76}$. at 280-81 (citations omitted).

77 See id. at 281-85. Although easily satisfying the Court's new balancing test, the regimes tested in Thomas v. Union Carbide Agricultural Products Co., 473 U.S. 568 (1985), and Commodity Futures Trading Commission v. Schor, 478 U.S. 833 (1986), bear no relation to that considered in Murray's Lessee, nor do they satisfy the public-rights test im- 
Some have found an anomaly in the public-rights doctrine. ${ }^{78}$ The public-rights doctrine, they hold, allows the federal government to decide nearly all claims between it and private parties without involving a judge with Section 1 security. But, of all matters in which separation of powers and judicial independence seem most compelling, they suggest, the public-rights area seems most crucial. There the government interest and temptation to influence decisionmakers seem the greatest. There an independent judiciary seems at its most valuable in protecting private parties. (And, they ask on the other hand, why have criminal matters not been included within the category? Simply ad hoc, for tradition's sake? Certainly they appear to embrace preeminent public rights, claims the government brings against private parties.)

Ironically, this generalization of the public-rights doctrine, a generalization intended to show its weaknesses and dangers, eases the Court's way into a balancing test. The anomaly becomes the paradigm. The public-rights doctrine has come to stand for the proposition that the greater the government's interest, the greater Congress's liberty to assign cases to officials without Section 1 security. Thus, the public-rights doctrine is taken to be not a formalistic, categorical "exception" to Article III, but rather a continuum along which Article I values weigh in against those of Article III. ${ }^{79}$

All this misses the point: The public-rights doctrine invites no such anomalous generalization. What makes a matter one of public rights is not the degree of government interest, but whether the right is one that falls to the executive to determine as a matter of public administration, at least for the time being. Using a test that weighs

plicit in the term "the judicial Power," the only textually based test they have any chance of satisfying. Each involved a right as between private parties, the right to compensation for research data, see Thomas, 473 U.S. at 571, and the right to recover on a debt, see Schor, 478 U.S. at 837-38. How a high degree of intimacy of a right with a federal regulatory scheme, see Thomas, 473 U.S. at 593-94, 600-01 (Brennan, J., concurring), or "necessity," see Schor, 478 U.S. at $843-44$, or waiver, see id. at $848-49$, authorizes a departure from the Constitution remains a mystery of the balance.

See, e.g., Redish, supra note 24, at 210 (discussing the potential constitutional flaws inherent in the public-rights doctrine); Young, supra note 1, at 837 (criticizing the public-rights doctrine and its encroachment on separation-of-powers logic); see also Kenneth S. Klein, The Validity of the Public Rights Doctrine in Light of the Historical Rationale of the Seventh Amendment, 21 HASTINGS CONST. L.Q. 1013 (1994) (arguing against the constitutional validity of the public-rights doctrine).

${ }^{79}$ At least one commentator saw this possibility two decades before Thomas and Schor. See Louis L. JAFFE, JuDicial CONTROL OF ADMINISTRATIVE ACTION 90 (1965) ('Public right' is an alchemical concept which with a little legerdemain can be used to transmute nearly any controversy into "one involving public rights."). 
the importance of the government interest would suggest that criminal law should be subject to the public-rights doctrine, because punishing a criminal with twenty years in prison is more important than collecting a hundred dollars of internal revenue. A criminal trial, however, pits the government against the defendant before a disinterested tribunal. The prosecution and defense stand before the court much as do the parties to a civil action. The court authoritatively speaks the law, not to guide the executive, but to resolve a dispute between parties at equal distance from itself. Collecting taxes, on the other hand, is an executive act which, although it requires the application of law to facts, remains an act of administration. This is true whether or not the tax officials wear black robes, sit on a bench, and are called judges of a court, ${ }^{80}$ because the nature and purpose of their business is to inform taxpayers of their bills. Before a federal court, the very same matter takes on a different nature. Instead of "in house" officials-however unbiased and fair-fine-tuning a tax assessment in a "legislative" court, in federal court the matter becomes a dispute between two parties submitting to a tribunal that will pronounce the law to resolve their dispute. ${ }^{81}$ The public-rights doctrine teaches simply that until brought before the judicial power, matters may remain the subject of administration, of the executive application of law to facts.

Two concurring opinions by Justice Scalia reflect this understanding of the judicial power and the public-rights doctrine. He wrote the first in Granfinanciera, S.A. v. Nordberg, in which the Court decided that the Seventh Amendment secures the right to trial by jury for fraudulent-conveyance actions tried in Bankruptcy Court. ${ }^{82}$ In so deciding, the Court held that such an action vindicates a private, not a public, right, because the reach of the Seventh Amendment and Article III are subject congruently to the force of the public-rights doc-

${ }^{80}$ But see Geier, supra note 16, at 994 (arguing that " [t] he Tax Court exercises only judicial power").

${ }^{81}$ This is a subtle, but not fatuous, distinction: Federal administrators may, for example, resolve back-pay disputes with employees of their agencies. They may study regulations, marshal facts, and allow employees and supervisors to submit evidence and argue issues. They may even don robes and sit behind large desks. They may call their decisions "orders." They may, in fact, mimic federal courts to a great extent. Nevertheless, all the while they will be performing an executive functiondetermining for a federal employer the amount of a paycheck. That the judicial power might also determine the amount of a paycheck under the appropriate circumstances does not gainsay this observation.

${ }^{82} 492$ U.S. 33 (1989). 
trine. The Court purported to use Justice Brennan's version of the Thomas test, a test that eschews the position that "“"a matter of public rights must at a minimum arise between the government and others," ",85 and instead asks whether "Congress, acting for a valid legislative purpose pursuant to its constitutional powers under Article I, [has] create[d] a seemingly 'private' right that is so closely integrated into a public regulatory scheme as to be a matter appropriate for agency resolution with limited involvement by the Article III judiciary." "\$4 The Nordberg Court held the fraudulent-conveyance action private, more a common-law suit than an integral part of restructuring debtor-creditor relations.

Justice Scalia could not agree that the public-rights doctrine reached cases to which the federal government was not a party. Instead, he argued, public rights extended only to claims "brought by or against the United States." ${ }^{85}$ He saw the doctrine as rooted in the doctrine of sovereign immunity: The Framers of the Constitution, he believed, contemplated "a discrete category of judicial acts" that, because they involved the government as a party, "were not thought to implicate a judicial controversy." resolve claims brought by it or against it without the need to make a federal case out of everything.

Justice Scalia further explained his views in a later concurrence, this one joined by three other Justices. Freytag $v$. Commissioner posed the question whether the chief judge of the Tax Court constitutionally could appoint a special trial judge. ${ }^{87}$ To do so, the chief judge must either act for a "Court[] of Law" or be the "Head[] of [a] Department[]." ${ }^{\prime 8}$ The Court answered that the chief judge of the Tax Court could indeed appoint the special trial judge, because the Tax Court was a court of law "exercis[ing] the judicial power of the

${ }^{83}$ Id. at 54 (Scalia, J., concurring) (quoting Northern Pipeline Constr. Co. v. Marathon Pipe Line Co., 458 U.S. 50, 69 (1982) (plurality opinion) (quoting Ex parte Bakelite Corp., 279 U.S. 438, 451 (1929))).

${ }_{84}$ Id. (Scalia, J., concurring) (alterations in original) (quoting Thomas v. Union Carbide Agric. Prods. Co., 473 U.S. 568, 593-94 (1985)).

${ }^{85}$ Id. at 68 (Scalia, J., concurring).

${ }^{86}$ Id. at 69 (Scalia, J., concurring).

501 U.S. 868 (1991).

${ }^{88} I d$ at 878,884 (quoting U.S. CONST. art II, $\$ 2, \mathrm{cl} .2$ ). The Appointments Clause provides: "[T] as they, think proper, in the President alone, in the Courts of Law, or in the Heads of Departments." U.S. CONST. art. II, § 2, cl. 2. 
United States." $\$ 99$ This is so, the Court opined, notwithstanding that the Tax Court was an Article I, not an Article III, court. Because the Tax Court acts like a court, deciding cases, examining witnesses, and applying law to facts, it is a "Court of Law" in the sense of the Appointments Clause. It could, therefore, through its chief judge, appoint a special trial judge.

Justice Scalia opined that the "Courts of Law" mentioned in the Appointments Clause have to be Article III courts, but that the chief judge of the Tax Court was a head of a department and, as such, could appoint a special trial judge. ${ }^{0}$ For our purposes, most significant were his remarks answering the Court's claim that the Article I Tax Court exercises "the judicial power of the United States"

Despite [the] unequivocal text [of Article III], the Court sets forth the startling proposition that "the judicial power of the United States is not limited to the judicial power defined under Article III." It turns out, however-to our relief, I suppose it must be said-that this is really only a pun. "The judicial power," as the Court uses it, bears no resemblance to the constitutional term of art we are all familiar with, but means only "the power to adjudicate in the manner of courts." So used, as I shall proceed to explain, the phrase covers an infinite variety of individuals exercising executive rather than judicial power (in the constitutional sense), and has nothing to do with the separation of powers or with any other characteristic that might cause one to believe that is what was meant by "the Courts of Law."

Regarding Article I tribunals, "[i] $\mathrm{t}$ is no doubt true that all such bodies 'adjudicate,' i.e., they determine facts, apply a rule of law to those facts, and thus arrive at a decision. But there is nothing 'inherently judicial' about 'adjudication." cer-not something intrinsic about the mode of decisionmaking or type of decision-that tells us whether the judicial power is being exercised. ${ }^{94}$ The Tax Court calculates taxpayers' bills, an executive

89 Freytag, 501 U.S. at 889.

See id. at 901 (Scalia, J., concurring in part and concurring in judgment).

91 Id. at 890.

92 Id. at 908 (Scalia, J., concurring in part and concurring in judgment) (quoting Freytag, 501 U.S. at 889).

Id. at 909 (Scalia, J., concurring in part and concurring in judgment).

94 Id. at 911 (Scalia, J., concurring in part and concurring in judgment). The Freytag Court relied in part upon dicta from Williams v. United States, 289 U.S. 553, 565 (1933), that suggested that legislative courts "are invested with judicial power." See Freytag, 501 U.S. at 889-91. Justice Scalia's concurrence disposes of the dicta, noting the condemnation Williams has received from commentators. See Freytag, 501 U.S. at 913 n.5 (Scalia, J., concurring in part and concurring in judgment). 
function, no matter the judicial "accouterments." ${ }^{95}$ In the forceful formalism typical of Justice Scalia, ${ }^{96}$ the opinion demonstrates that the public-rights doctrine is rooted in the text of the Constitution, not in a pragmatic exception to the text. The term "the judicial Power" itself speaks to the context of applying law to fact. Not all adjudications involve the judicial power. To adjudicate public rights within executive agencies is not to exercise the judicial power.

A proper distinction between the judicial power and the executive power shows that the Constitution does not call for judges with Section 1 security in the categories of courts-martial and public-rights actions. Decisions within these two categories fall to executive officers whose tenure and compensation are left by the Constitution to political and prudential determinations. The categories are not exceptions to the text of Article III, for the text does not purport to embrace them.

\section{TERrITORIAL COURTS AND THE JUDICIAL POWER "OF THE UNITED STATES"}

In American Insurance Co. v. Canter, ${ }^{97}$ the Court upheld a tribunal authorized by act of Congress for the territory of Florida. ${ }^{98}$ Its judges enjoyed a tenure of only four years. But Chief Justice John Marshall explained that, because the Superior Courts of Florida were "legislative," not "constitutional," courts, their judges need not have Section 1 security. ${ }^{99}$ True, the courts were "incapable of receiving"

${ }^{95}$ See Freytag, 501 U.S. at 912 (Scalia, J., concurring in part and concurring in judgment).

${ }^{66}$ See Plaut v. Spendthrift Farm, Inc., 514 U.S. 211, $239-40$ (1995) (Scalia, J.) (stating that separation of powers "establish[es] high walls and clear distinctions .... . Good fences make good neighbors."); Granfinanciera, S.A. v. Nordberg, 492 U.S. 33, 70 (1989) (Scalia, J., concurring in part and concurring in the judgment) (criticizing Commodity Futures Trading Commission v. Schor, 478 U.S. 833 (1986), and stating that separation of powers "must be anchored in rules, not set adrift in some multifactored 'balancing test"); Scalia, supra note 33, at 1185 ("I believe that the establishment of broadly applicable general principles is an essential component of the judicial process ...."). For an in-depth study of Justice Scalia's rule-based formalism, see Eric J. Segall, Justice Scalia, Critical Legal Studies, and the Rule of Law, 62 GEO. WASH. L. REV. 991,1005 (1994).

${ }_{97} 26$ U.S. 511, 1 Pet. 388 (1828).

${ }^{98}$ Congress vested "the whole judicial power of the territory 'in two Superior Courts, and in such inferior Courts, and justices of the peace, as the legislative council of the territory may from time to time establish."' 26 U.S. at 543, 1 Pet. at 413 . The territorial legislature thereafter constituted the tribunal whose act was at issue. See id.

${ }^{99}$ Id. at 545-46, 1 Pet. at 413-14. 
the judicial power of the United States. ${ }^{100}$ Nevertheless, the Superior Courts' exercise of the admiralty jurisdiction vested in them by Congress did not violate Article III. ${ }^{101}$ These courts were creatures of Article $I$, and their existence and operation had nothing whatsoever to do with Article III.

So begins, it is said, the hoary tradition of exceptions to the text of Article III. ${ }^{102}$ Congress authorized the establishment of the Florida territorial courts. Congress invested them with jurisdiction, including admiralty jurisdiction. But because Congress has "plenary power" over territorial government, somehow Article III presents no problem. In fact, as the argument runs, Canter must be carving an exception out of the text of Article III; otherwise, the Canter Court itself never could have heard the case: The matter either was or was not within the judicial power of the United States. ${ }^{109}$ If it was, the Florida courts must have exercised the judicial power of the United States, notwithstanding Chief Justice Marshall's rhetoric, and so the Chief Justice created an exception to Article III. If the matter was not within the judicial power of the United States, the federal courts, including the Supreme Court, should have dismissed Canter for want of subject matter jurisdiction. So, the argument concludes, Canter must be understood to hold that Article III-despite its text and obvious applicability to territorial courts-somehow does not constrain Congress's establishment of territorial courts. ${ }^{104}$ Article III has undergone judicial amendment.

Wrong. Article III was not amended in Canter or in any of the other cases that find no constitutional impediment to congressional statutes establishing courts for the territories or the District of Columbia. ${ }^{105}$ The courts that Congress establishes for such polities under its control are not truly United States courts. They, like state

${ }^{100} I d$.

${ }^{101}$ See id.

${ }^{102}$ See, e.g., Fallon, supra note 1, at 921-26 (discussing cases that are incompatible with Article III literalism).

${ }^{103}$ See Canter, 26 U.S. 511, 1 Pet. 388.

104 See Northern Pipeline Constr. Co. v. Marathon Pipe Line Co., 458 U.S. 50, 10607 (1982) (White, J., dissenting) (drawing the above conclusions from Canter); Glidden Co. v. Zdanok, 370 U.S. 530, 54447 (1962) (plurality opinion) (discussing Canter and concluding that "practical considerations" led Chief Justice Marshall to "recognize[] a greater flexibility in Congress to deal with problems arising outside the normal context of a federal system").

${ }^{105}$ See Palmore v. United States, 411 U.S. 389, 400-01 (1973) (discussing Congress's authority to create territorial courts). 
courts, are courts of their respective polities. ${ }^{106}$ The polity of territorial Florida had its courts, as does the State of Florida today. Yet, whereas today the State of Florida provides courts for itself, Congress provided courts for territorial Florida. ${ }^{107}$ That the decisions of these courts could be reviewed by the United States Supreme Court, as in Canter, did not negate the fact that the Florida territorial court was, with Congress's authority, exercising the judicial power of the territory, a polity other than the United States, when deciding a case in admiralty. ${ }^{108}$ Similarly, state courts exercise state judicial power over cases, even though the federal judicial power also "extends" to them ${ }^{109}$ and will be exercised if they are reviewed in the United States Supreme Court. ${ }^{110}$ Even when state courts decide types of cases and controversies that are listed in the Constitution as within the judicial power of the United States, cases and controversies for which review may lie in the United States Supreme Court, ${ }^{111}$ the judicial power these state courts exercise is their own. ${ }^{112}$ So it is with territorial courts. $^{113}$

106

See Reynolds v. United States, 98 U.S. 145, 154 (1878) (noting that the territorial courts may have the same jurisdiction as circuit and district courts but are not "circuit or district courts of the United States"); Hornbuckle v. Toombs, 85 U.S. (18 Wall.) 648,656 (1873) ("[T]he jurisdiction of the Territorial courts is collectively coextensive with and correspondent to that of the State courts."); Clinton v. Englebrecht, 80 U.S. (13 Wall.) 434, 447 (1871) ("The judges of [the territorial court] are appointed by the President under the act of Congress, but this does not make the courts ... courts of the United States."); Benner v. Porter, 50 U.S. (9 How.) 235, 244 (1850) ("The Territorial courts ... .were not courts in which the judicial power conferred by the Constitution on the Federal government could be deposited.").

${ }^{107}$ See U.S. CONST. art. IV, § 3, cl. 2.

${ }^{108}$ Section 9 of the Judiciary Act of 1789 , ch. 20, 1 Stat. 73, 76, made federal admiralty jurisdiction exclusive of state admiralty jurisdiction. See Romero v. International Terminal Operating Co., 358 U.S. 354, 359-80 (1959) (detailing the development of state and federal admiralty jurisdiction). Nothing in this provision, however, is inconsistent with an act of Congress that invests a territorial court with admiralty jurisdiction. See The "City of Panama", 101 U.S. 453, 458-59 (1879) (holding, as in Canter itself, that the territorial court, unlike a state court, had jurisdiction of admiralty cases).

${ }^{109}$ See Houston v. Moore, 18 U.S. 1, 27-28, 5 Wheat. 1, 13 (1820) ("[T] he state courts may exercise jurisdiction on cases authorized by the laws of the state, and not prohibited by the exclusive jurisdiction of the federal Courts.").

${ }^{110}$ See Martin v. Hunter's Lessee, 14 U.S. 304, 338, 1 Wheat. 141, 156 (discussing the extension of federal appellate jurisdiction to state tribunals).

111 See U.S. CONST. art. III, \$ 2.

112 See THE FEDERALIST No. 82, at 493 (Alexander Hamilton) (Clinton Rossiter ed., 1961) (opining that state courts have jurisdiction over every case not "excluded by the future acts of the national legislature").

113 See Freytag v. Commissioner, 501 U.S. 868, 913 (1991) (Scalia, J., concurring in part and concurring in judgment) (stating that territorial courts "are neither Article 
Again, as with courts-martial and public rights, the analysis to be used is that given by the Court itself in the leading case. In Canter, Chief Justice Marshall did not emphasize the plenary power of Congress over territories, as if such a power were so great as to license Congress to trample Article III. Instead, he distinguished between two types of congressional legislation for two distinct polities:

The jurisdiction with which [the Florida territorial courts] are invested, is not a part of that judicial power which is defined in the $3 \mathrm{~d}$ article of the Constitution, but is conferred by Congress, in the execution of those general powers which that body possesses over the territories of the United States. Although admiralty jurisdiction can be exercised in the states, in those Courts only, which, are established in pursuance of the third article of the constitution; the same limitation does not extend to the territories. In legislating for them, Congress exercises the combined powers of the general, and of a state government. ${ }^{114}$

Territorial courts (and the courts of the District of Columbia) exercise the judicial power of their respective polities. ${ }^{115}$ Though creations of Congress, these courts fall outside the terms of Article III, because they do not exercise the judicial power of the United States. Their judges need not enjoy Section 1 security.

This constitutional distinction between territorial Article I legislative courts and Article III courts is sound. Article III ensures that state courts will not be supplanted by a federal judiciary that is subservient to the President or to Congress. Federal politics are to be confined to the two political branches. Whatever tenure each state might prescribe for its own judges, ${ }^{116}$ it is protected from improper federal influence upon litigation involving its citizens in that the judges of courts invested with the judicial power of the United States are to

III courts nor Article I courts, but Article IV courts-just as territorial governors are not Article I executives but Article IV executives").

${ }^{114}$ American Ins. Co. v. Canter, 26 U.S. 511, 546, 1 Pet. 388, 415 (1828); see also JOSEPH STORY, COMMENTARIES ON THE CONSTITUTION OF THE UNITED STATES § 849, at 605-06 (Ronald D. Rotunda \& John E. Nowak eds., Carolina Academic Press 1987) (1833) (describing the courts of the territories of the United States as legislative rather than Article III courts). As to the exclusive nature of admiralty jurisdiction, see supra note 108.

${ }^{115}$ See supra note 98.

116 "Federal judges have life tenure, whereas judges in forty-six of the fifty states face some form of electoral review." Erwin Chemerinsky, Parity Reconsidered: Defining a Role for the Federal Judiciary, 36 UCLA L. REV. 233, 275-76 (1988); see Edward Hartnett, Why Is the Supreme Court of the United States Protecting State Judges from Popular Democracy?, 75 TEX. L. REV. 907, 975 (1997) (explaining that "[o]nly three states ... give judges what some call life tenure"). 
have Section 1 security. ${ }^{117}$ But, when "the People," through the Constitution, entrusted Congress with authority to act in the manner of a local legislature with respect to territories or the District of Columbia, ${ }^{118}$ they intended Congress to establish courts as Congress deems best, without regard to Article III. In such cases, Congress has as much liberty in shaping a judiciary for a polity as a state does in shaping its own courts. Federalism does not have the same sway as it does for federal courts within the states, courts that exercise the judicial power of the United States. ${ }^{119}$ Congress, like a state legislature, might invest judges of territorial courts with good-behavior tenure; then again, like almost all state legislatures, it might not. ${ }^{120}$

As with courts-martial and executive agencies acting to determine matters of public rights, territorial legislative courts exist not by virtue of an exception to Article III, adopted by prescription, despite the text of the Article. To the contrary, territorial legislative courts exist because the text of Article III does not reach them. Though established by the United States Congress, they do not exercise the judicial power of the United States.

\section{ADJUNCTS, "JUdGES," AND "COURTS"}

In the 1932 maritime case of Crowell $v$. Benson, ${ }^{121}$ the Supreme Court held that a deputy commissioner of a federal administrative agency-though lacking Section 1 security-could lawfully award an

117 See THE FEDERALIST No. 78, supra note 3 (discussing how good-behavior tenure for judges will protect the public).

${ }^{118}$ See U.S. CONST. art. IV, $\S 3$ ("The Congress shall have Power to dispose of and make all needful Rules and Regulations respecting the Territory or other Property belonging to the United States ...."); id. art. I, § 8, cl. 17 (giving Congress the power "[t]o exercise exclusive Legislation in all Cases whatsoever, over such District... as may ... become the Seat of the Government of the United States"); Palmore v. United States, 411 U.S. 389, 397-99, 402-04 (1973) (discussing congressional authority under Articles I and III to enact laws for and vest jurisdiction in the District of Columbia, the states, and the territories).

119 And "the need for judicial independence from Congress in the administration of local District [of Columbia] law is arguably less than the need for independence that exists when national laws are being administered." Ralph U. Whitten, Consent, Caseload, and Other Justifications for Non-Article III Courts and Judges: A Comment on Commodities Futures Trading Commission v. Schor, 20 CREIGHTON L. REV. 11, 19 (1986). Congress may not be as inclined to interfere in such cases. See id. ("Members of Congress ... probably do not care as much about the administration of local justice in the District [of Columbia] ... and this lessens the likelihood that they will intervene to pressure District of Columbia judges to reach particular results.").

${ }^{120}$ See supra note 116.

121285 U.S. 22 (1932). 
injured employee compensation against his private employer under the Longshoremen's and Harbor Workers' Compensation Act. ${ }^{122}$ Federal courts were available to enforce, modify, suspend, or set aside such awards. The Crowell Court agreed that legislation providing for such awards did not violate Article III. ${ }^{23}$ When courts divide their work between judges and other judicial officers, Article III requires only that an arrangement "maintain the essential attributes of ... judicial power." "Other judicial officers" come in various forms. Common-law courts use juries. Equity and admiralty courts use "masters, and commissioners or assessors." Likewise, the Crowell Court held, Congress may assign factfinding powers to administrative agencies, reserving to federal courts the determination of questions of law.

Crowell began what is called the "adjunct" exception to Article III. ${ }^{126}$ As long as adjunct decisionmakers exercise no "essential attributes of the judicial power, ${ }^{, 27}$ this exception permits them to exercise "some" of the judicial power. ${ }^{128}$ Congress is also said to have more ability to vest the judicial power in adjunct decisionmakers when it creates the rights at issue. ${ }^{129}$ The fewer powers of a court an agency

${ }^{122} 33$ U.S.C. $\$ \S 901-950$ (1994).

${ }^{123}$ See Crowell, 285 U.S. at 49-50. A majority of the Court reasoned that the award involved the deputy commissioner in no factfinding that would bind a federal court as to constitutional or jurisdictional issues. The federal court reviewing the validity of the award would be free to find "fundamental or jurisdictional facts" for itself. Id. at 62 . Justice Brandeis, with two others, dissented, writing that Article III offered no impediment whatever to administrative adjudication. See id. at 86-88 (Brandeis, J., dissenting).

Later cases seem to have jettisoned the majority's quibbles regarding constitutional and jurisdictional facts. See Northern Pipeline Constr. Co. v. Marathon Pipe Line Co., 458 U.S. 50, 82 n.34 (1982) (plurality opinion) (citing St. Joseph Stock Yards Co. v. United States, 298 U.S. 38, 53 (1936)). But see CHEMERINSKY, supra note 1, § 4.4, at 226 ("In general, Crowell remains good law in that [constitutional] facts may be relitigated, de novo, in an Article III federal court." (footnote omitted)).

${ }^{124}$ Crowell, 285 U.S. at 51.

125 Id

126 See CHEMERNNSKY, supra note $1, \S 4.4$, at 225-27 (discussing Crowell and the "adjunct" theory).

${ }^{127}$ Northern Pipeline, 458 U.S. at 77 (plurality opinion) (citing Crowell, 285 U.S. at 51).

${ }^{128}$ Id. at 78-79, 81, 87 (plurality opinion); see id. at 87-89 (plurality opinion) (holding that the Bankruptcy Act of 1978 "has impermissibly removed most, if not all, of 'the essential attributes of the judicial power' from the Art. III district court, and has vested those attributes in a non-Art. III adjunct" (quoting the Bankruptcy Reform Act, 28 U.S.C. $\$ 1471(1994))$ ).

${ }^{129}$ See id. at 80 (plurality opinion) (" $[1] \mathrm{t}$ is clear that when Congress creates a substantive federal right, it possesses substantial discretion to prescribe the manner in 
possesses, the more likely it is to be viewed as an "adjunct" to the federal courts, and therefore an acceptable exception to the Article III regime. $^{130}$

The "adjunct" theory, in fact, works no exception to Article III..$^{131}$ While the Crowell opinion lacks a clear statement of how the text of Article III supports the adjunct theory, Article III is, in itself, rather clear. The text of Article III never vests "the judicial Power" of the United States in judges, let alone judges with Section 1 security. The judicial power is vested in courts, the judges of which shall have the required security. ${ }^{132}$

The arrangement, then, is not one of judicial power shared between a federal court and another agency, where the "essential attributes" of power inhere in the former but not the latter. ${ }^{133}$ All of the judicial power must vest in the court. ${ }^{134}$ What is at issue is which duties render a decisionmaker a "judge" for purposes of Article III, thereby requiring that individual to possess Section 1 security. Offi-

which that right may be adjudicated-including the assignment to an adjunct of some functions historically performed by judges.").

${ }^{130}$ See id. at 87 (plurality opinion) (stating that a grant of court-like power to an adjunct cannot be sustained).

${ }^{131}$ See Geras v. Lafayette Display Fixtures, Inc., 742 F.2d 1037, 1045-54 (7th Cir. 1984) (Posner, J., dissenting) (discussing and applying an adjunct theory rooted in the text of Article III).

${ }^{132}$ This fact has occasionally gone unnoticed in discussions of Article III. See, e.g., Redish, supra note 24, at 226 ("Article III vests the 'judicial power' in judges ...."). Or if noticed, the importance of this fact has been minimized. See Linda J. Silberman, Master and Magistrates Part II: The American Analogue, 50 N.Y.U. L. REV. 1297, 1300-04 (1975) (acknowledging that "no provision of the Constitution inextricably links the exercise of power with the article III judge," but nonetheless stating that courts exercise the judicial power "through article III judges").

${ }^{139}$ In cases before Crowell, the Supreme Court did not protest the use of special masters or auditors by federal judges. In one instance, the Court even held that a judge should have been more deferential to a special master's findings. See Kimberly v. Arms, 129 U.S. 512, 524 (1889) ("In practice it is not usual for the court to reject the report of a master, with his findings upon the matter referred to him ...."). Courts, it stated in another case, have "inherent power" that "includes authority to appoint persons unconnected with the court to aid judges in the performance of specific judicial duties." Ex parte Peterson, 253 U.S. 300, 312 (1920).

${ }^{134}$ Black's Law Dictionary gives this as part of its definition of "Court":

An organized body with defined powers, meeting at certain times and places for the hearing and decision of causes and other matters brought before it, and aided in this, its proper business, by its proper officers, viz., attorneys and counsel to present and manage the business, clerks to record and attest its acts and decisions, and ministerial officers to execute its commands, and secure due order in its proceedings.

BLACK'S LAW DICTIONARY, supra note 41 , at 352 . Based on this definition alone, a court is clearly more than its judges. 
cials of the executive branch may act as officers of federal courts, as "adjuncts," without violating Article III. ${ }^{\text {IS5 }}$ They become, for constitutional purposes, court personnel. But only court personnel with Section 1 security serve as "judges."

The question remains how to determine what duties render a decisionmaker a "judge" in the constitutional sense. As with "the judicial Power," so with "judges" one must decode this term with reference to the common usage of $1789 .{ }^{1.77}$ The line between judge and adjunct-between judge and jury, special master, commissioner, assessor, or other nonjudge personnel of the court-is drawn by Article III. ${ }^{138}$ If an administrative regime respects this line, it does not violate Article III. ${ }^{139}$ As long as "judges" with Section 1 security perform all "judging," Article III leaves Congress free to constitute courts with subalterns as it sees fit, ${ }^{140}$ possibly even filling courts with agents of the executive. ${ }^{141}$

${ }^{135}$ Whether doing so breaches some other provision of the Constitution, such as the Appointments Clause, U.S. CONST. art. II, $\$ 2, \mathrm{cl}$. 2, is not addressed here.

${ }^{136}$ The distinction between a judge and his court would have been well known to the Framers. Judges of the English common-law courts by themselves at home or in chambers could enter orders on minor matters. By the late-18th century, such orders, though binding if accepted by the parties, were nevertheless not considered orders of the court. For the court to enforce the order, it must first have been made an order of the court and not just of a judge of the court. See A.S. Diamond, The Queen's Bench Master, 76 LAw Q. REV. 504, 504-06, 506 (1960) ("[T] he judge's order was not an order of the court. [One] would first need to apply to the court to make the judge's order a rule of court ...."). A 1782 case raising the question whether published criticisms of an action Lord Chief Justice Mansfield took sitting in chambers could be contempt of court may have caught the eye of a Framer or two. See id. at 506.

${ }^{137}$ See supra note 39.

193 See Michael H. v. Gerald D., 491 U.S. 110, $127-28$ n.6 (1989) (plurality opinion) (noting the level-of-generality question inherent in analyzing historical or traditional meanings). This question presents itself in distinguishing between judge and adjunct: does the distinction follow the specific offices of 1789 practice or instead the principle that animated the practice? Probably most faithful to the text, using as it does only the word "judge" to circumscribe in composite the diverse roles of adjuncts, is the approach that looks to practices and offices contemporaneous with the adoption of the text to establish a general definition of the word "judge" as distinguished from adjunct. That is the approach taken in this Article. Furthermore, such a general definition reflects a principled distinction that accords with the textual provision of Section 1 security for judges only. See infra text accompanying notes 142-50.

${ }^{159}$ The term "line" is not intended to suggest solely a bifurcation of duties without reference to the relationship to be maintained between judges and adjuncts. The "line" might be crossed when judges insufficiently supervise or manage adjuncts.

${ }^{140}$ See Laura B. Bartell, Contempt of the Bankruptcy Court-A New Look, 1996 U. ILL. L. REV. 1, 27 (characterizing bankruptcy judges as "administrative functionaries, wearing black robes and bearing an exalted title").

${ }^{141}$ But see supra note 135. 
Perhaps the history of chancery provides the most help in defining the traditional division between judges and nonjudge officials within a court. ${ }^{142}$ Although the matter is in some dispute, it seems that the masters in chancery, who aided the Chancellor, were seen in the eighteenth century as adjuncts of the court and not as judges:

"[T]he ... Masters in Chancery, have exercis'd, and at this day do exercise judicial authority in the court of Chancery: But it is one thing to exercise judicial authority in a court, and another thing to be a Judge of that court, every officer of a court who assists and helps the Judge in the exercise of judgment, so far as such assistance goes, does a judicial act, but yet he is not thereby the Judge. He that is the Judge of a court, must be the supreme, and final determiner of matters within the same court, and must be able to judge of all matters within the jurisdiction of the court, and must likewise have power to execute and make effectual all his judgments and decrees." ${ }^{143}$

Adjuncts and judges both exercise the judicial authority of a court, but the judge, not the adjunct, ultimately decides and effects the judgment. It seems that eighteenth-century America transplanted the office of master in chancery, along with, to some degree, the distinction between adjunct and judge. ${ }^{144}$ In addition to the office of master in chancery, the office of commissioner would also have been familiar to the framers of Article III. Commissioners took depositions to gather facts in chancery cases. ${ }^{145}$ Since 1793, officers (named "commissioners" in 1812) have assisted United States courts in the adjudication of criminal matters. ${ }^{146}$ This English and early American

142 See generally 1 WILlIAM HOLDSWORTH, A HISTORY OF ENGLISH LAW 416-21 (A.L. Goodheart \& H.G. Hanbury eds., 7th rev. ed. 1956) (1903) (discussing the development of the office of masters in chancery to provide assistance to the Chancellor).

${ }^{143}$ James R. Bryant, The Office of Master in Chancery: Early English Development, 40 A.B.A. J. 498, 501 (1954) (quoting SAMUEL BURROUGHS, THE LEGAL JUDICATURE IN ChANCERY 56 (London, J. Walthoe 1727)). Chief Judge Posner, citing Blackstone, understands that "the Lord Chancellor reviewed the masters' decrees de novo." Geras v. Lafayette Display Fixtures, Inc., 742 F.2d 1037, 1046 (7th Cir. 1984) (Posner, J., dissenting) (citation omitted).

${ }^{144}$ See James R. Bryant, The Office of Master in Chancery: Colonial Development, 40 A.B.A. J. 595, 598 (1954) (discussing the transplantation of masters of chancery into American colonial courts).

${ }^{145}$ See 3 BLACKSTONE, supra note 41 , at $* 449$ (discussing the order and method of depositions in England as compared to that in the 13 colonies).

${ }_{146}$ See Richard W. Peterson, The Federal Magistrate Act: A New Dimension in the Implementation of Justice, 56 IOWA L. REV. 62, 66-67 (1970) (discussing the powers of commissioners, including "issu[ing] warrants for arrest, commitment, and admittance to bail"); Joseph F. Spaniol, Jr., The Federal Magistrates Act: History and Development, 1974 ARIz. ST. L.J. 565, 566-67 (discussing the roles played by magistrates in taking bail in 
tradition should help distinguish adjuncts from judges. ${ }^{147}$ The text of Article III embraces this tradition in using as it does the terms of art "Courts" and "Judges."

As previously shown, ${ }^{148}$ finding a formalist, textual solution to a constitutional question is not fleeing reason and principle to find a refuge in words, but rather finding reason and principle expressed in words. In providing for federal courts, the judges of which are to have Section 1 security, Article III strikes a balance born of both reason and principle. Protecting judges from political pressures is necessary to prevent tyranny, ${ }^{149}$ protecting all court officials, however, is not necessary, and would invite inefficiency and expense. A broader constitutional protection might even have compromised the authority of judges by limiting their ability to govern their own courts. Giving judges, but not other court officers, good-behavior tenure had worked well for the English courts. ${ }^{150}$ Article III, with good reason and upon sound principle, makes a like distinction among court officers.

Like the other "exceptions" this Article has examined-courtsmartial, public-rights cases, and territorial courts-the adjunct exception is no exception. If the proper constitutional distinction is made between judges and other officers of the court, the adjunct theory respects the text of Article III.

\section{CONCLUSION}

"In considering this question [of the scope of the enumerated powers], then, we must never forget that it is a constitution we are ex-

criminal cases and describing the background and legislative history of the Federal Magistrates Act).

${ }^{147}$ The tradition suggests that, at some point, an Article III "judge" must become involved in a full adjudication employing an "adjunct." See supra note 143 and accompanying text. But see Constitutional Analysis, supra note 13, at 291-302 (drawing a contrary conclusion from the precedents, including a dozen from the courts of appeals directly on point). Whether litigants, by waiver or agreement, may elect to permit the work of judges to be performed by adjuncts to the court is also a question to be answered from this tradition. It may be that election has no bearing on the role of judge and adjunct. See Geras, 742 F.2d at 1054 (Posner, J., dissenting) (stating that requiring parties' consent to trial by magistrate does not make 28 U.S.C. $\$ 636$ (c) comport with the purpose, let alone the text, of Article III).

See supra text accompanying notes 70, 80-81, and 116-20.

${ }^{149}$ See supra note 5.

${ }^{150}$ See THE FEDERALIST No. 78, supra note 3, at 465 (praising good-behavior tenure); F.W. MAITLAND, THE CONSTITUTIONAL HISTORY OF ENGLAND 312-13 (1920) (discussing the historical role of good-behavior tenure in England). 
pounding." ${ }^{\text {"151 }}$ Chief Justice John Marshall did not mean that the text before him invited judicial revision, but rather that it invited an uncrabbed interpretation faithful to the text. Article III requires the same faithful interpretation. It has no need of exceptions. The text of the Constitution permits courts-martial, territorial courts, executive adjudication of public rights, and the participation of judicial adjuncts-all without the protection of Section 1 security. ${ }^{152}$ Granted, these institutions and practices must be held to limits absent from the present balancing test. To conclude that the Constitution allows them is not to conclude that it allows them necessarily as they appear today. What the Constitution does is to provide principled guidance, a rule of law, regarding the incidence of Section 1 security. The provenance of the so-called "exceptions" to Article III rests upon the Constitution, not upon an unprincipled departure from the Constitution under the guise of historical necessity. To adopt a balancing test is to abandon their rationale, not to justify it.

${ }^{151}$ McCulloch v. Maryland, 17 U.S. 316, 407, 4 Wheat. 159, 200 (1819).

152 This reading of the text accords well with Alexander Hamilton's shorthand summary that "all judges who may be appointed by the United States are to hold their offices during good behavior," THE FEDERALIST No. 78, supra note 3, at 465 . Section 1 security does not run to executive officers, to judges appointed by territorial authorities (even if those authorities happen to be also the President or Congress of the United States), or to nonjudge officers of courts. 